\title{
CORRESPONDENCE
}

\section{Certain misconceptions regarding Late Palaeozoic rocks in Tasmania}

SIR - In a recent issue of Geological Magazine (110 (4), p. 314) I was disturbed to see a further repetition of the much quoted (Waterhouse, 1969, 1970, 1971 $a, b$ ) occurrence of 'Tatarian' marine faunas [and tillite] in the Ferntree Group of Tasmania. I should like to take this opportunity of drawing your attention to the following:

(1) Permo-Carboniferous and Triassic rocks, which have recently been named the Parmeener Super-Group (Banks, 1973), are widespread in Tasmania. Although they are often much faulted, they are almost everywhere subhorizontal. Large areas of their outcrop have been mapped by the Geological Survey of Tasmania at a scale of $1: 15840$ to $1: 12500$.

(2) Frequently the Parmeener Super-Group commences with a thick basal tillite which also contains subordinate glaciolacustrine rhythmite clay and turbidite sandstone layers. These basal tillite sequences are poorly fossiliferous but the available evidence indicates that they range in age from Late Carboniferous (Stephanian) to Early Permian (Sakmarian) (Banks, in Gulline, 1967; Jago, 1972; Clarke \& Banks, in press; Clarke, Farmer \& Gulline, in press; Clarke, Banks \& Gulline, in press). Tillite is unknown above this level within the Parmeener Super-Group.

(3) Above the basal tillite, the lower parts of the Parmeener Super-Group are predominantly marine. Glacially derived dropstones remain much in evidence and occur in association with very rich, but low diversity shelly faunas of Permian age and Gondwanan aspect. Ten informal assemblage faunizones are currently recognised (Clarke \& Banks, in press). In essence the Tasmanian faunas agree with those sequences of faunas recorded from elsewhere in eastern Australia (Dickins, Malone \& Jensen, 1964; Dickins, 1968, 1970; Runnegar, 1967, 1969). Although correlation of the Gondwanan Eurydesma Fauna with the world standard is difficult, most workers (Dickins, 1968; 1970; Runnegar, 1969) consider that the youngest eastern Australian marine faunas are no younger than Late Kungurian or Early Kazanian.

(4) Clarke (1973) refutes in detail both the occurrence of tillite and the associated Late Permian (Tatarian or Waiitian) faunas in the Ferntree Group of Tasmania. The faunas obtained from the locality cited by Waterhouse (1969) and ten additional localities within the Ferntree Group, are all broadly consistent and are almost identical with those recorded from the New Zealand Flettian Stage. The Flettian Stage is regarded as Late Kungurian or Early Kazanian in terms of the world standard by Waterhouse (1964 et seq.), Dickins (1968 et seq.) and Runnegar (1969 et seq.).

\section{References}

Banks, M. R. 1967. In Gulline, A. B. The first proved Carboniferous deposits in Tasmania. Aust. J. Sci. 29, 332-3.

Banks, M. R. 1973. General geology. In: The Lake Country of Tasmania, pp. 25-34. Royal Society of Tasmania.

Clarke, M. J. 1973. Faunas from the Ferntree Group of south-eastern Tasmania. Tech. Rep. Dep. Mines Tasm. 16, 50-65.

Clarke, M. J. \& Banks, M. R. (in press). The stratigraphy of the lower (Permo-Carboniferous) parts of the Parmeener Super-Group, Tasmania. Proc. 3rd Int. Gondwana Symp. A.N.U. Press, Canberra.

Clarke, M. J., Banks, M. R. \& Gulline, A. B. (in press). Carboniferous System, Tasmania. Stratigraphic Lexicon. Vol. VIII. Carboniferous. UNESCO, Paris.

Geol. Mag. 111 (6), 1974, pp. 565-567. Printed in Great Britain. 
Clarke, M. J., Farmer, N. \& Gulline, A. B. (in press). Parmeener Super-Group, Tasmania. Economic Geology of Australia and Papua-New Guinea (Petroleum Volume). Australas. Inst. Min. Metall.

Dickins, J. M. 1968. Correlation of the Permian of the Hunter Valley, New South Wales, and the Bowen Basin, Queensland, Bull. Bur. miner. Resour. Geol. Geophys. Aust. 80, 27-44.

Dickins, J. M. 1970. Correlation and subdivision of the Permian of Western and Eastern Australia. Bull. Bur. miner. Resour. Geol. Geophys. Aust. 116, 17-28.

Dickins, J. M., Malone, E. J. \& Jensen, A. R. 1964. Subdivision and correlation of the Permian Middle Bowen Beds, Queensland. Rep. Bur. miner. Resour. Geol. Geophys. Aust. 70.

Jago, J. B. 1972. Geology of the Maydena Range. Pap. Proc. R. Soc. Tasm. 106, $45-56$.

Runnegar, B. 1967. Preliminary faunal zonation of the eastern Australian Permian. Qd Govt Min. J. 68, 552-6.

Runnegar, B. 1969. The Permian faunal succession in eastern Australia. Spec. Publs. geol. Soc. Aust. 2, 73-98.

Waterhouse, J. B. 1964. Permian brachiopods of New Zealand. Palaeont. Bull. geol. Surv. N.Z. 35, 287 pp.

Waterhouse, J. B. 1969. World correlations of New Zealand Permian Stages. N.Z. $J l$ Geol. Geophys. 12, 713-37.

Waterhouse, J. B. 1970. The world significance of New Zealand Permian stages. Trans. R. Soc. N.Z. 7, 97-109.

Waterhouse, J. B. $1971(a)$. Correlation of the marine Permian faunas for Gondwana. 2nd Int. Gondwana Symp. 381-94. D.S.I.R., South Africa.

Waterhouse, J. B. $1971(b)$. The Permian brachiopod genus Terrakea Booker, 1930. Smithson. Contr. Paleobiol. 3, 347-61.

Geological Survey of Tasmania

M. J. CLARKE

Department of Mines

G.P.O. Box 124B, Hobart

Tasmania, Australia, 7001

6th December 1973.

SIR - In the late Permian of New Zealand, glaciation is strongly suggested by shallowwater red and green siltstones, followed by slump-breccia then tillite, and carbonates with cold-water faunas described by Waterhouse (1967). The fauna is correlated with the late Permian Gujo fauna of Japan, and thence to the Bellerophonkalk of Austria-Italy, and the Phisonites-Comelicania Zone of Armenia and Iran. All are referred to the Vedian Stage (Waterhouse, 1972), based on Armenian outcrops and faunas.

When Mr M. J. Banks of the Department of Geology, University of Tasmania, as I have fully acknowledged, showed me what he said was a late Ferntree tillite near Hobart I naturally concluded that this was likely to be of the same age. If Tasmanian geologists wish to revise their local facies and age interpretation, the publishing of a letter to such effect, avoiding mention of Mr Banks' role, is as good a means as any. It appears that I may have erred in identifying Tomiopsis magna with Tomiopsis antesulcata from the tillite - or now ill-sorted pseudotillitic conglomerate - time will tell when the faunas are described.

It is to be hoped that when the faunas are described Dr Clarke will use terms of correlation to replace the subdivisions of the authorities he quotes, used in Russia before the second world war. Terms such as Sakmarian (s1) or Tatarian have no place in a modern stage nomenclature for the Permian, as shown by Furnish (1973). Probably the failure to understand recent advances has led Runnegar $(1967,1969)$ to include late Middle Permian (Chiddruan) faunas from Queensland as well as Vedian faunas of New Zealand in the 'Kazanian Stage', as shown in Table 1, or Clarke in his letter hesitantly to ascribe the 'Eurydesma' fauna to late Carboniferous or Sakmarian. Of course Eurydes- 
matidae are definitely found in Kurmain, Sterlitamakian and Filippovian faunas, and may be Suren =Stephanian in part as well, in both New South Wales and Argentina.

Table 1. Permian correlations, from Waterhouse $(1973 a, b)$

\begin{tabular}{|c|c|c|c|c|}
\hline \multicolumn{2}{|c|}{ World standard stage } & \multirow{2}{*}{ New Zealand biozone } & \multicolumn{2}{|c|}{ Runnegar } \\
\hline Stage & Substage & & 1967 & 1969 \\
\hline Dorashamian & $\left\{\begin{array}{l}\text { Ogbinan } \\
\text { Vedian }\end{array}\right.$ & Aperispirifer nelsonensis* & 一 & - \\
\hline Djulfian & $\left\{\begin{array}{l}\text { Baisalian } \\
\text { Urushtenian }\end{array}\right.$ & $\begin{array}{l}\text { Durvilleoceras woodmani } \\
\text { Spinomartinia spinosa }\end{array}$ & Kazanian & \\
\hline Punjabian & $\left\{\begin{array}{l}\text { Chhidruan } \\
\text { Kalabaghian }\end{array}\right.$ & $\begin{array}{l}\text { Plekonella multicostata } \\
\text { Martiniopsis woodi }\end{array}$ & & Kazanian \\
\hline Kazanian & $\begin{array}{l}\text { \{ } \begin{array}{l}\text { Sosnovian } \\
\text { Kalinovian }\end{array} \\
\text { Ufimian }\end{array}$ & $\begin{array}{l}\text { Terrakea brachythaerum } \\
\text { Echinalosia ovalis } \\
\text { Notospirifer spinosa }\end{array}$ & & \\
\hline Kungurian & $\left\{\begin{array}{l}\text { Elkin } \\
\text { Nevolin } \\
\text { Filippovian }\end{array}\right.$ & $\begin{array}{l}\text { Echinalosia maxwelli } \\
\text { Spiriferella supplanta } \\
\text {-* }\end{array}$ & Artiskian & \\
\hline Baigendzinian & $\begin{array}{l}\left\{\begin{array}{l}\text { Krasnoufimiar } \\
\text { Sarginian } \neq ?\end{array}\right. \\
\text { Aktastinian } \\
\text { Sterlitama- }\end{array}$ & $\begin{array}{l}\text { Echinalosia prideri } \\
\text { Martinia adentata } \\
\text { Notostrophia homeri }\end{array}$ & & \\
\hline Sakmarian & $\left\{\begin{array}{l}\text { Sterlitama- } \\
\text { kian } \ddagger \\
\text { Tastubian }\end{array}\right.$ & - & & \\
\hline Asselian & $\left\{\begin{array}{l}\text { Kurmaian } \dagger \\
\text { Uskalik } \\
\text { Suren } \ddagger ?\end{array}\right.$ & $\begin{array}{c}\text { (Mourlonia impressa) } \\
- \\
-\end{array}$ & Sakmarian & \\
\hline
\end{tabular}

* Tillite horizon.

$\dagger$ Main Eurydesma horizon of Gondwana; $\ddagger$ Other Eurydesmatid horizons.

\section{References}

Furnish, W. M. Permian Stage Names. In Logan, A. \& Hills, L. V. (Eds): The Permian and Triassic systems and their mutual boundary. Mem. Can. Soc. Petrol. Geol. 2. $522-48$.

Runnegar, B. 1967. Preliminary faunal zonation of the eastern Australian Permian. Qd Govt Min. J. 68, 552-6.

Runnegar. B. 1969. The Permian faunal succession in eastern Australia. Spec. Publn Geol. Soc. Aust. 2, 73-98.

Waterhouse, J. B. 1967. Upper Permian (Tatarian) brachiopods from New Zealand. N.Z. Jl Geol. Geophys. 10 (1), 74-118.

Waterhouse, J. B. 1972. The evolution, correlation and paleogeographic significance of the Permian ammonoid family Cyclolobidae. Lethaia 5, 251-70.

Waterhouse, J. B. 1973(a). Heirarchy and Significance of environmental parameters for brachiopods: the New Zealand Permian model. Life Sci. Contr. R. Ont. Mus. 92, $1-49$.

Waterhouse, J. B. 1973(b). Permian brachiopod correlations for south-east Asia. Bull. geol. Soc. Malaysia 6, 187-210. 